УДК 330.3:338.2

JEL classification: E61, F43, J31, L12, 011

\section{Йосиф СИтник}

доктор економічних наук, доцент, завідувач, кафедра менеджменту персоналу та адміністрування,

Національний університет "Львівська

політехніка», Україна

E-mail: yosyf.s.sytnyk@lpnu.ua

ORCID ID: 0000-0001-8718-5738

Researcher ID: R-5946-2017

(c) Йосиф Ситник, 2021

Отримано: 01.02.2021 p.

Прорецензовано: 12.02.2021 р.

Рекомендовано до друку: 24.02.2021 р.

Опубліковано: 24.02.2021 p.

\section{(c) (†) (5)}

Ця стаття розповсюджується на умовах ліцензії Creative Commons AttributionNonCommercial 4. 0, яка дозволяє необмежене повторне використання, розповсюдження та відтворення на будь-якому носії, за умови правильного цитування оригінальної роботи.
Йосиф Ситник (Україна)

\section{ТРАНСФОРМАЦІЙНИЙ ВПЛИВ ІНСТИТУЦІЙНИХ БАР'ЄРІВ НА ЗРОСТАННЯ НАЦІОНАЛЬНОЇ ЕКОНОМІКИ УКРАїНИ}

АНОТАЦІЯ

Вступ. Економічне зростання та економічний розвиток будь-якого соціальноекономічного простору $є$ запорукою гідного рівня життя в державі. Зазначені категорії потрібно розглядати як незворотні та спрямовані якісні зміни складноорганізованої системи, що саморозвивається через призму формування інституційних передумов і ризиків. Потребують наукової уваги теоретичні та методологічні проблеми, що стосуються нової моделі економічного зростання і розвитку в Україні.

Мета. Визначення тенденцій і чинників нестабільного економічного зростання й встановлення причинно-наслідкових зв'язків задовільного розвитку національної економіки України та окреслення теоретичноприкладних засад щодо зміни економічної моделі й управління нею.

Метод. Застосовано теоретико-методологічний інструментарій, який базується на традиційному підході та методи логічного узагальнення, аналізу, порівняння й синтезу до оцінювання обсягів, темпів та структури економічного зростання на основі низки макроекономічних показників.

Результати. У статті досліджено динаміку національного економічного зростання в Україні за період 2000-2019рр. на основі емпіричних показників. Виокремлено та класифіковано ключові чинники, які разом із структурною, демографічною, валютною та банківською кризами й галопуючою інфляцією спричинили різкі економічні перепади у темпах економічного зростання. Розглянуто тенденції виробничої структури валового внутрішнього продукту (ВВП) України за основними видами економічної діяльності та її вплив на економічне зростання. Здійснено порівняння ВВП на душу населення в Україні із іншими країнами Європи, та виявлено істотні відмінності за рівнем цього показника. Проаналізовано чинники інфляційних і девальваційних процесів, а також політику державного боргу на динаміку економічного зростання. Розроблено класифікацію й виокремлено групи інституційних бар'єрів (концентраційно-власницькі, управлінсько-інституційно-лідерські, регресивно-антиінноваційні, воєнно-політичні й зовнішньоекономічні), які унеможливлюють економічне зростання в національній економіці України. Окреслено головні завдання, які потрібно паралельно вирішити в національній економіці України у середньостроковій перспективі для забезпечення внутрішнього зростання і розвитку.

Ситник Й. Трансформаційний вплив інституційних бар'єрів на зростання національної економіки України. Економічний аналіз. 2021. Том 31. № 1. С. $196-210$.

DOI: https://doi.org/10.35774/econa2021.01.196

Ключові слова: зростання; розвиток; валовий внутрішній продукт; інфляція; девальвація; капітал; концентрація; монополізм; олігархія; інновація; знання. 
UDC 330.3:338.2

\section{JEL classification: E61, F43, J31, L12, 011}

\section{Yosyf SYTNYK}

Doctor of Sciences (Economics),

Associate Professor,

Head,

Department of Human Resource Management and Administration,

Lviv Politechnic National University, Ukraine

E-mail: yosyf.s.sytnyk@Ipnu.ua

ORCID ID: 0000-0001-8718-5738

Researcher ID: R-5946-2017

(C) Yosyf Sytnyk, 2021

\section{Received: 01.02.2021}

Revised: 12.02 .2021

Accepted: 24.02 .2021

Online publication date: 24.02 .2021

This is an Open Access article, distributed under the terms of the Creative Commons AttributionNonCommercial 4. 0 license, which permits unrestricted re-use, distribution, and reproduction in any medium, provided the original work is properly cited.

\section{TRANSFORMATION INFLUENCE OF INSTITUTIONAL BARRIERS ON THE GROWTH OF THE NATIONAL ECONOMY OF UKRAINE}

\begin{abstract}
Introduction. Economic growth and economic development of any socioeconomic space is the key to a decent standard of living in the state. These categories should be considered as irreversible and targeted qualitative changes in a complex system that develops itself through the prism of the formation of institutional preconditions and risks. Theoretical and methodological problems related to the new model of economic growth and development in Ukraine need scientific attention.

Goal. Identification of tendencies and factors of unstable economic growth and establishment of causal relations of satisfactory development of the national economy of Ukraine and delineation of theoretical and applied bases concerning change of economic model and its management.

Method. Theoretical and methodological tools based on the traditional approach and methods of logical generalization, analysis, comparison and synthesis to assess the volume, rate and structure of economic growth based on a number of macroeconomic indicators.

Results. The article examines the dynamics of national economic growth in Ukraine for the period 2000-2019 on the basis of empirical indicators. The key factors that, together with the structural, demographic, currency and banking crises and galloping inflation, caused sharp economic fluctuations in economic growth rates, have been identified and classified. The tendencies of the production structure of the gross domestic product (GDP) of Ukraine by the main types of economic activity and its influence on economic growth are considered. The comparison of GDP per capita in Ukraine with other European countries was made, and significant differences in the level of this indicator were revealed. The factors of inflation and devaluation processes, as well as the policy of public debt on the dynamics of economic growth are analyzed. A classification has been developed and groups of institutional barriers (concentration-ownership, managerial-institutional-leadership, regressive-anti-innovation, military-political and foreign economic) have been identified, which prevent economic growth in the national economy of Ukraine. The main tasks that need to be solved in parallel in the national economy of Ukraine in the medium term to ensure domestic growth and development are outlined.
\end{abstract}

Sytnyk, Y. (2021). Transformation influence of institutional barriers on the growth of the national economy of Ukraine. Economic analysis, 31 (1), 196-210.

DOI: https://doi.org/10.35774/econa2021.01.196

Keywords: growth; development; grosses domestic product; inflation; devaluation; capital; concentration; monopoly; oligarchy; innovation; knowledge. 
www.econa.org.ua

\section{Вступ}

Національний економічний розвиток України за минуле двадцятиліття зумовлювався впливом низки цілеспрямованих, домінантних та взаємопов'язаних процесів - концентрації капіталу, монополізації ринків, деіндустріалізації, агресивної глобалізації й хаотичної регіоналізації та демографічного спаду. Відтак актуальною $\epsilon$ проблема з'ясування причин циклічності стагнації економічного розвитку України та окреслення суспільно прийнятної моделі економічного зростання, яка б забезпечувала ефективність на макроекономічному рівні, так і на рівні секторальному, територіальних громад, формування економічних можливостей та справедливого розподілу національних ресурсів i доданої вартості серед суб'єктів господарювання, власників і найманих працівників.

Досягненню окреслених цілей щодо аналізування зазначених процесів сприятиме застосування теоретико-методологічного інструментарію, який базується на традиційному підході до оцінювання обсягів, темпів та структури економічного зростання за допомогою низки макроекономічних показників.

Теоретичні та прикладні аспекти розвідки стосовно проблематики економічного зростання та ринкових реформи в посткомуністичних країнах висвітлено у праці О. Гаврилишина [2], досвід трансформації економічних систем у ЦентральноСхідній Європі й Україні та концептуальні засади модернізації національної економіки на засадах економічної безпеки розкрито в монографії за редакцією О. Власюка і А. Мокія [4], дослідження місця України у світових рейтингах за рівнем ВВП, індексом добробуту та індексом щастя розглянуто авторами О. Фоміна, Н. Гоголєва, Ю. Лабузова [23], дослідження детермінант експортоорієнтованого розвитку в умовах неопротекціонізму XXI століття та ідентифікація рівня експортної орієнтованості економіки України на основі комбінаторного підходу висвітлено у статті К. Пугачевської [14], трансформації економічної поведінки соціуму у процесі соціально-економічного розвитку присвячена праця Р. Шеремети і О. Романенко [15], аналіз принципів i найважливіших чинників стабільного зростання та вплив світової економічної кризи на зростання і розвиток різних країн досліджено у праці лауреата Нобелівської премії М. Спенса [19], а також співвідношення економічного зростання та добробуту нації через призму безробіття і нерівності розкрито у праці Г. Макстона та Й. Рандерса [9].

У контексті цього дослідження частина завдання полягає у правильному визначенні проблеми. Протягом крайніх двадцяти років національна економіка України діяла у двосторонній гібридній системі 3 різними фактичними правилами та практиками для монопольних капіталоконцентрованих секторів економіки та сектору малого і середнього підприємництва. Оскільки, в українській економіці, пріоритети й політику всеосяжно диктували приватні монополії через законодавчо-інституційні та фіскальнобюджетні механізми, саме вони контролювали структурні процеси і зміни в економіці та фінансову систему. Водночас незначний прошарок середнього класу й підприємницько-інноваційне середовище, мали штучно ускладнений набір пріоритетів й можливостей свого зростання і розвитку та були цілком залежні від монополістів. Потребують наукової уваги теоретичні та методологічні проблеми, що стосуються нової моделі економічного зростання і розвитку, забезпечення структурної гнучкості, моделювання правильних координаційних взаємодій між державним регулюванням і ринковими механізмами для досягнення ефективності.

\section{Мета статті}

Метою дослідження $€$ визначення чинників нестабільного економічного зростання і встановлення причинно-наслідкових зв'язків задовільного розвитку національної економіки України та окреслення теоретично-прикладних засад щодо зміни економічної моделі й управління нею.

\section{Виклад основного матеріалу}

У теоретично-онтологічному аспекті зміст категорій «економічне зростання» і «економічний розвиток» дослідники трактують у різний спосіб. Одні вважають ці економічні категорії тотожними, а інші - розмежовуючи їх розглядають через призму кількісних та якісних змін, або взаємозв'язку причина - наслідок, які залежать, як від економічних, так і неекономічних чинників.

На думку ґ. Макстона і Й. Рандерс, економічне зростання - це підвищення загальної продуктивності економіки за певний проміжок часу, що зазвичай вимірюється в кількості відсотків на рік, а загальна продуктивність $€$ ринковою вартістю усіх товарів та послуг, вироблених у країні за певний проміжок часу, з урахуванням вартості вкладень, з поправкою на торгівлю [9, с. 36].

Згідно трактування НБУ, стійке (стале) економічне зростання - позитивні темпи зростання валового внутрішнього продукту (ВВП) та валового національного доходу (ВНД) на душу населення впродовж тривалого часу, яких можна досягти без накопичення макроекономічних дисбалансів, наприклад, високої та мінливої інфляції, значного нарощування боргу тощо. Відтак короткотермінового економічного зростання можна досягти, стимулюючи сукупний попит, але 
www.econa.org.ua

таке «підштовхування» має свою ціну - штучні «ін'єкції» для підтримки попиту призводять до розкручування інфляції 3 відповідними дестабілізуючими наслідками для макроекономічного розвитку та добробуту громадян. Іншим негативним наслідком такої політики є втрата довіри до національної валюти як з боку населення, так і бізнесу, а ії відновлення потребуватиме вжиття органами влади значних цілеспрямованих зусиль упродовж тривалого часу. Тому, основою тривалого економічного зростання $\epsilon$ збільшення продуктивності факторів виробництва, тобто знаходження шляхів ефективнішого використання наявних ресурсів [21].

Нобелівський лауреат і знаний американський економіст українського походження, фахівець 3 питань національного доходу та теорії економічного зростання С. Кузнец (Коваль) виокремив низку критеріїв економічного зростання, властивих майже усім розвинутим країнам [28]:

- високі темпи зростання доходу на душу населення і кількості населення;

- високі темпи зростання продуктивності факторів виробництва, особливо за рахунок технічного прогресу;

- високі темпи структурної трансформації економіки;

- високі темпи соціальної, політичної та ідеологічної трансформації;

- міжнародні масштаби економічного зростання зумовлені здатністю розвинутих країн у минулому і сьогодні знаходити за кордоном ринки збуту, джерела сировини і дешевої робочої сили, що призводить до політичного і економічного поневолення бідних країн;

- обмеження розповсюдження результатів економічного зростання.

Економічне зростання має власну систему показників, на основі яких характеризується його кількісний чи якісний стан. До них належать такі показники: річні темпи зростання ВВП (ВНП) або національного доходу у відсотках; абсолютний приріст національного доходу або ВВП (ВНП) за рік; приріст національного доходу на душу населення за відповідний період. [3]:

Відомі декілька моделей (видів) зростання ВВП

- зростання, пов'язане зі збільшенням чисельності населення країни;

- зростання, пов'язане зі збільшенням виробництва продукції, в силу підвищення частки країни в міжнародній торгівлі (модель зростання А. Сміта);

- зростання, пов'язане зі збільшенням інвестицій і заощаджень (модель зростання Р. Солоу);
- зростання, викликане технологічним прогресом країни (модель зростання Й. Шумпетера).

Хоч це і парадокс, але за крайні 20 років в українських реаліях національної економіки не реалізована жодна із моделей зростання ВВП.

На відміну від економічного зростання, економічний розвиток будь-якого соціальноекономічного простору потрібно розглядати як незворотні та спрямовані якісні зміни складноорганізованої системи, що саморозвивається. Загалом, економічний розвиток, вважається, суперечливим процесом, який не $\epsilon$ лише прямолінійним, а характеризується нерівномірністю, чергуванням періодів зростання і спаду, кількісними і якісними змінами в економіці, переходом системи в новий або кращий/гірший стан. Тобто, економічний розвиток: має місце і тоді, коли зростання не відбувається, але закладені передумови для зростання економіки в майбутньому; економічний розвиток може виражатися i в структурних перетвореннях, які безпосередньо не призводять до економічного зростання; економічний розвиток може відбуватися і по низхідній лінії, коли не тільки відсутнє кількісне зростання, але йде процес зниження якості товарів та послуг [17].

Узагальнюючи викладене, варто зазначити, що економічне зростання - це лише статистика документування певного аспекту змін стосовно динамічного збільшення реального ВВП країни, яке $€$ органічною складовою економічного розвитку, його кількісним проявом, та яке охоплює значно вужче коло взаємозв'язків, ніж економічний розвиток. Водночас економічний розвиток $є$ якісноструктурною зміною усієї економічної системи, передбачає переважно висхідний і просторовий вертикально-горизонтальний перехід від одного її рівня взаємовідносин до іншого та забезпечує підвищення добробуту всіх верств населення. В матеріальній сфері він характеризується створенням можливостей для продуктивної й творчої праці, зменшенням нерівності у доходах, доступом до освіти й медичного обслуговування, деконцентрацією національного капіталу, диференціацією і високою технологічністю нових видів діяльності та збільшенням частки самодостатнього середнього класу у суспільстві. Економічне зростання і розвиток прямують паралельно із розвитком духовності (цінностей, релігії, культури), які загалом створюють свободу й можливості реалізації потенціалу націй.

3 огляду на теоретичне підґрунтя зазначеної проблематики проаналізую динаміку національного економічного зростання та економічного розвитку в Україні за період 20002019 рр. на основі емпіричних показників, зокрема таких: індексу фізичного обсягу ВВП; індексу 
www.econa.org.ua

промислової продукції; виробничої структури ВВП; обсягом ВВП на душу населення; динаміки реального ВВП та темпів приросту державного боргу й інфляції.

Українська економіка на мапі країн світу, сортованих за обсягом у структурі глобального ВВП, розрахованого за ринковою вартістю всіх товарів та послуг вироблених у 2018 році була розташована на 57 місці серед 190 країн учасниць та мала частку лише 0,15\% (рис. 1). Водночас частка десяти найпотужніших економік світу у цій структурі складає понад 65\%, частка трійки лідерів США,
Китаю і Японії - 45,4\%, частка країн ЄС - 21,8\%, а окремо США - 23,8\%.

Зважаючи на чисельність населення України, площу території, багатство природних ресурсів, рівень інтелектуального та виробничого потенціалу, можна стверджувати що потенціал українського ВВП є як мінімум у 5-7 разів більшим. Такий висновок, зокрема, підтверджують показники порівняння України із низкою країн світу співставних за чисельністю населення у 2018 році (рис. 2).

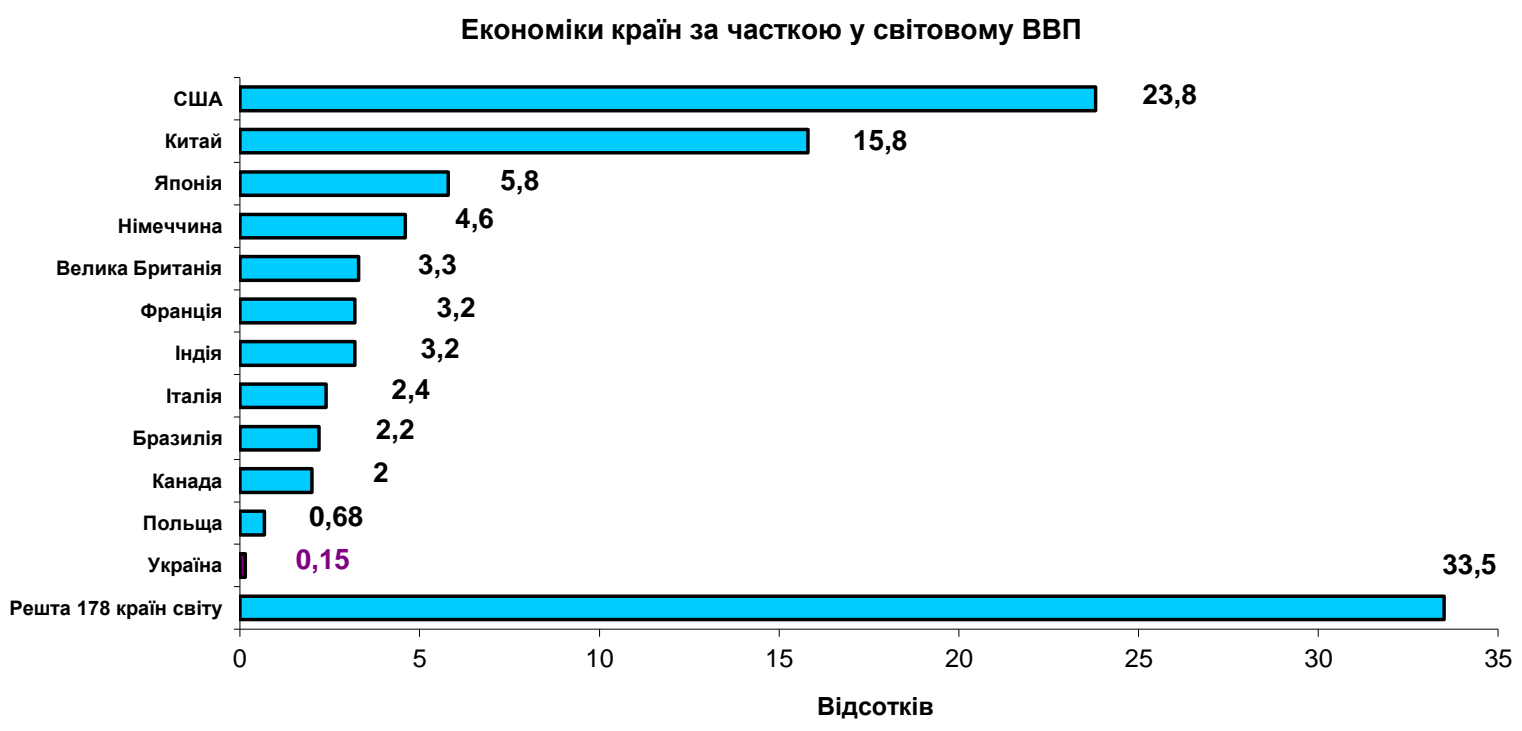

\section{Рис. 1. Вагомість України серед найпотужніших економіки країн світу за часткою в глобальному ВВП у 2018 році [29].}

Параметр обсягу номінального ВВП і ВВП на душу населення у 2018 р. (рис. 3), свідчить, що: ВВП Канади в понад 13 разів більший за ВВП України; ВВП Іспанії більший в 11 разів від українського; у Польщі у 4,5 разів; Колумбії у 2,5 рази більший за ВВП України. Постають логічні питання: Чому? Які економічні причини такого стану? Можливо причини не лише економічні, а світоглядні та інституційно-управлінські? Чи можливо чинна економічна модель національної господарки та стратегія і тактика трансформаційних змін в Україні за крайні 10-15 р. суперечать національним інтересам українців? Відповіді на ці та інші питання $€$ важливими у контексті цього дослідження.

Динаміка номінального валового внутрішнього продукту України за період 2000-2019 рр. свідчить, що його зростання у гривневому еквіваленті фактичних цін (рік до попереднього року) було постійним (рис. 4). Обсяг ВВП у 2019 р. порівняно із 2000 р. збільшився у 22,5 рази із 176,1 млрд. грн. до 3974,6 млрд. грн. Проте зваживши на девальвацію національної грошової одиниці гривні за цей період на 625,7\%, розрахований ВВП України у доларах США за ці роки, вказує на його циклічну динаміку зростання (рис. 5).

Обсяг ВВП у 2019 р. порівняно із 2000 р. у доларовому еквіваленті збільшився лише у 4,7 рази із 32,4 млрд. дол. США. до 153,8 млрд. дол. США. Найбільше зростання обсягу ВВП України у доларовому еквіваленті було досягнуто у 2008 р. 188,4 в млрд. дол. США, проте після економічної кризи 2008-2009 рр. ВВП у 2009 р. зменшилося до 121,6 млрд. дол. США. Економічне зростання та відновлення попередньо досягнутого рівня тривало аж до 2013 р. - 183,4 млрд. дол. США. У 2014-2015 рр. знову різкий спад у два рази до рівня 91,1 млрд. дол. США.

Протягом 2000-2010 рр. в Україні реальні темпи зростання були вищі у 2-3 рази (4,8\% в середньому за період), ніж у Японії - 1,4\% та Німеччині - 2,2\%. Як зазначають дослідники [17], основною причиною економічного зростання в цей період можна назвати збільшення завантаження наявних потужностей в економіці, створення сприятливих умов для стимулювання інвестиційної діяльності, зовнішню політику держави, яка сприяла 


\section{www.econa.org.u}

реформуванню економіки, а також підвищення внутрішнього попиту на товари і послуги за рахунок збільшення реальних доходів населення, розширення експортних ринків.

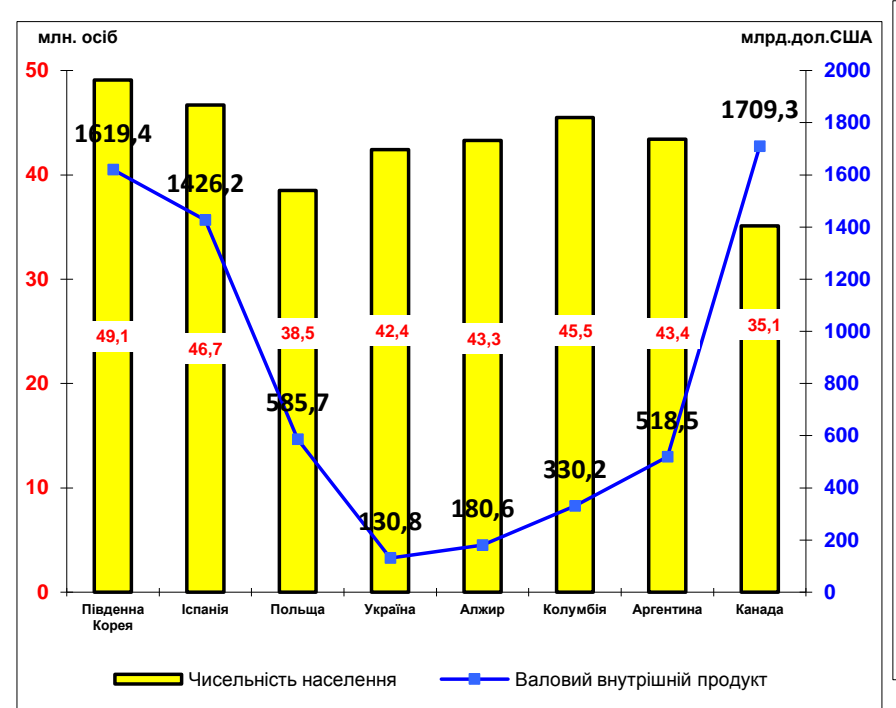

Рис. 2. Порівняння чисельності населення і обсягу ВВП в окремих країнах світу в 2018 р. [29]

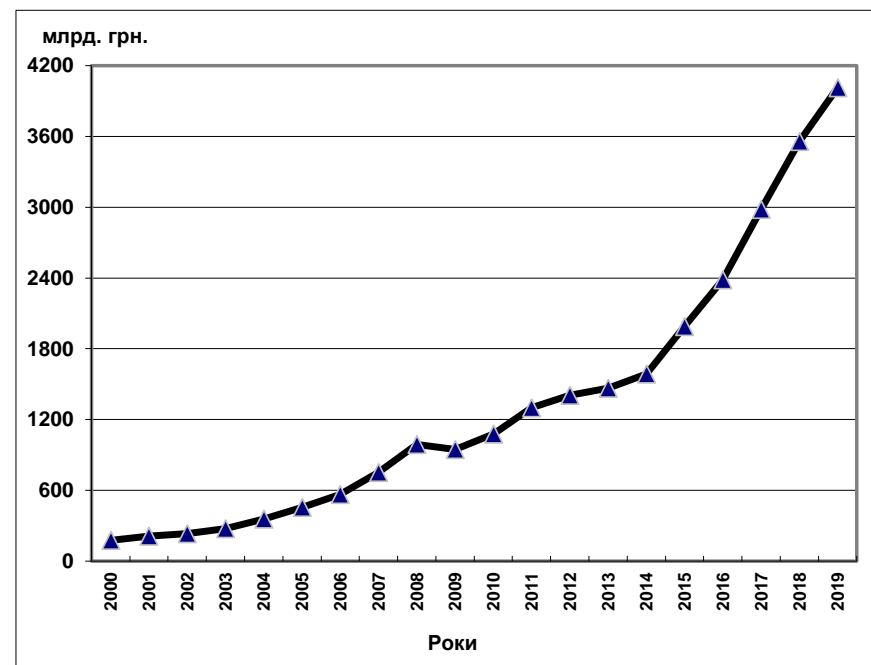

Рис. 4. Динаміка номінального ВВП України [20].

Проте, зростання економіки в цей період, як зазначає автор, в значній мірі було компенсаційним, відтворювальним. Водночас за період 2000-2019 рр. в Україні середні реальні темпи зростання становили 2,65\%, але упродовж 2010-2019 рр. реальні темпи зростання у середньому склали лише 0,48\%. Така негативна низхідна динаміка економічного зростання спричинена не лише об'єктивними чинниками економічної кризи 2008-2009рр., російськоукраїнською війною та анексією Криму і частини Донбасу, але й низкою інших більш системних, інституційних та монополістичних причин.

Ще у 2008 році, український академік А. Чухно $[24$, с. 6] авторитетно застерігав, що Україна будує економічну політику виключно на ринковій теорії, i

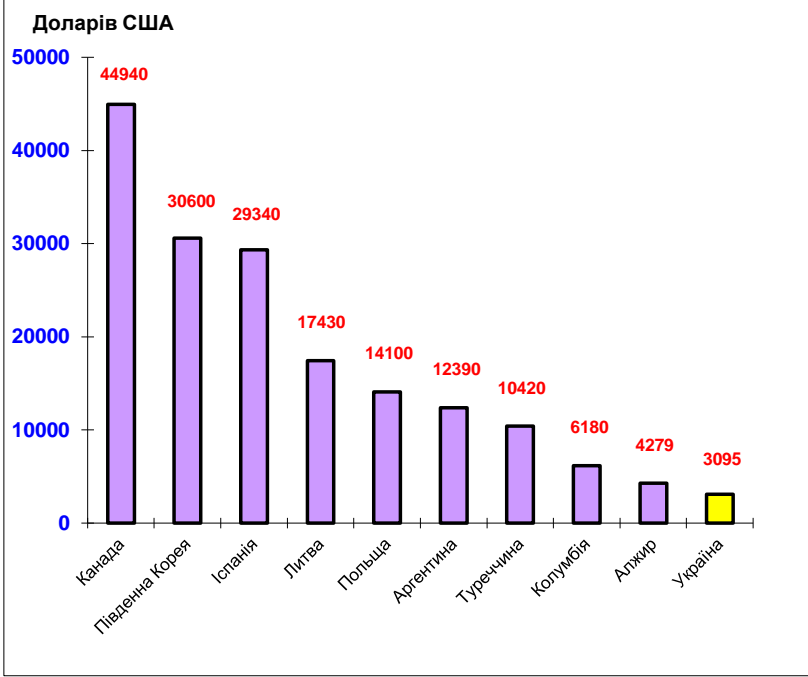

Рис. 3. ВВП на душу населення в окремих країнах світу за 2018 р. [29]

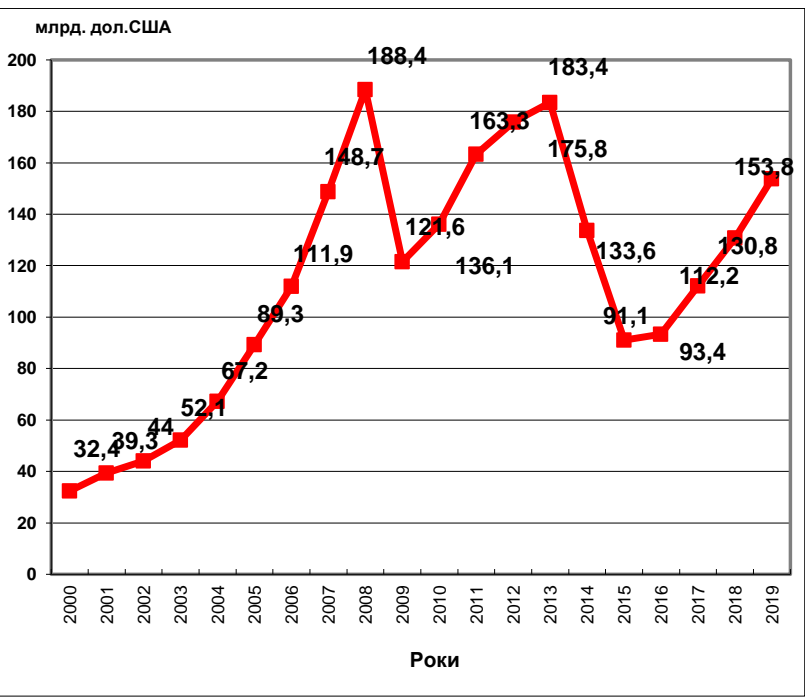

Рис. 5. Динаміка номінального ВВП України [20].

при цьому зовсім не враховує об'єктивний процес становлення нового технологічного способу виробництва. Це призвело до того, що ринкові перетворення було обмежено реформуванням виробничих відносин (приватизацією, роздержавленням), а науково-технологічне вдосконалення виробництва, зміни структури економіки залишились осторонь, хоча без них неможливий успішний розвиток країни. Іншими чинниками, на наш погляд, $€$ - насаджування агресивно-ліберальної економічної моделі, формування приватних монополій, концентрація капіталу та власності тощо.

Порівняльна динаміка індексів фізичного обсягу ВВП та промислової продукції за період 2000-2019 років, свідчить про нестабільність розвитку 
www.econa.org.ua

української економіка, різкі падіння обох показників у 2009 р. та 2014-2015 рр. та їх щільний кореляційний зв'язок, а також незначні прирости, які мають короткотривалі ефекти (рис. 6). Водночас виробнича структура ВВП України за основними видами економічної діяльності вказує на те, що основними джерелами його формування $€$ оптова та роздрібна торгівля, податки на продукти та переробна промисловість яка має тенденцію до зниження своєї частки із 17,4 \% до 10,8 \%, а також

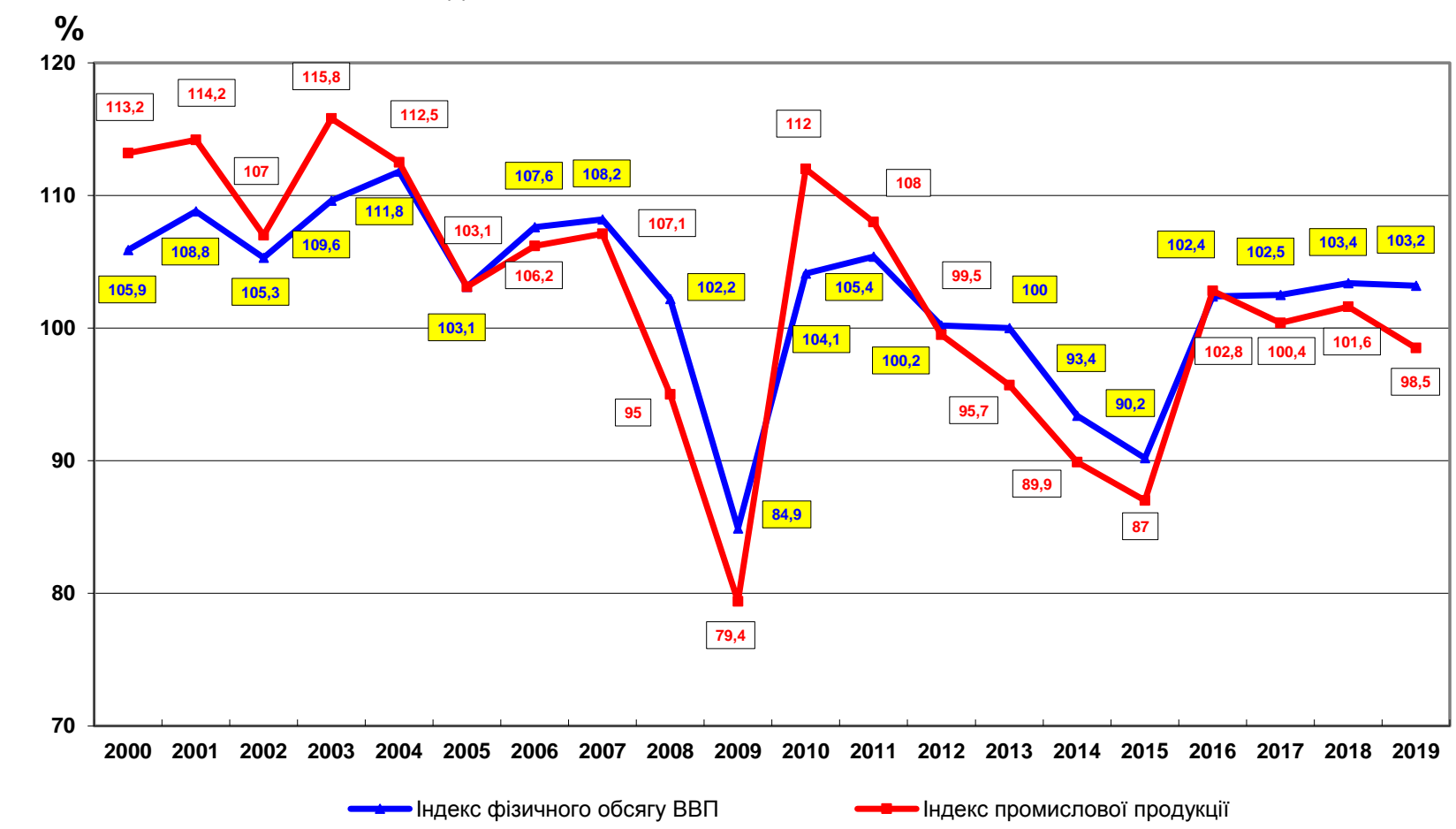

сільське господарство із тенденцією мінливої циклічності (рис. 7).

Аналіз структури ВВП за видами економічної діяльності свідчить про сировинну модель економіки, зокрема значну частку добувної промисловості, яка у період різкого зменшення на 1/3 частки переробної промисловості (2006-2011 рр.) із $18,7 \%$ до $11,9 \%$, збільшила свою питому вагу майже у двічі із 3,8\% до 6,5\%.

Рис. 6. Індекси фізичного обсягу ВВП та промислової продукції України (\% до попереднього року, 2010=100\% (для 2000-2018)) [20]

Водночас попри динамічне зростання, за минуле двадцятиліття, у світовій економіці нових видів діяльності заснованих на інформаційнокомунікаційних технологіях, питома вага сектору інформація та телекомунікації в національній економіці України збільшилася лише на 1,7 в.п., із 2,8\% у 2000 р. до 4,5\% у 2019 р. Це свідчить про те, що більшість суб'єктів підприємництва цього виду діяльності функціонують на умовах підрядних виконавців робіт у міжнародних структурах, а виробництво їхнього завершального продукту (програмне забезпечення) i додана вартість обліковується не в Україні, а за її межами.

Аналіз галузевої структури економіки розвинених регіонів України свідчить про те, що провідну роль в господарстві цих територій займають галузі, пов'язані з видобутком і обробкою корисних копалин. Території, недостатньо багаті на такі ресурси, значно відстають у соціальноекономічному розвитку [17].

Причиною застою такої структури ВВП та сировинної моделі економіки $€$ надмірна концентрації національного капіталу різних галузей економіки у руках 0,001\% населення (олігархів), які не зацікавлені інвестувати в інновації.

Дослідження науковців засвідчили, що чим нижчий рівень економічного розвитку країни та недосконаліша існуюча в ній інституціональна система, тим вищий рівень концентрації акціонерної власності [18, с. 62]. Водночас концентрація капіталу в Україні $€$ найбільшою серед усіх країн Центральної та Східної Європи [8, c. 17].

Узагальнювальним показником, що характеризує рівень економічного зростання суспільства, $€$ ВВП на душу населення. Цей показник у 2000-2008 рр. демонстрував доволі стійку динаміку середнього зростання за період на рівні 22,7\% (табл. 1). Темпи приросту протягом 2000-2010 рр. становили в середньому 17\%., за період 2000-2019 рр. - 11,2\%, а протягом 2010-2019 рр. лише 5,4\%. Найбільше зростання показника зафіксовано у 2007 і 2008 рр. понад 33\%, як у гривневому, так і в доларовому еквіваленті. 


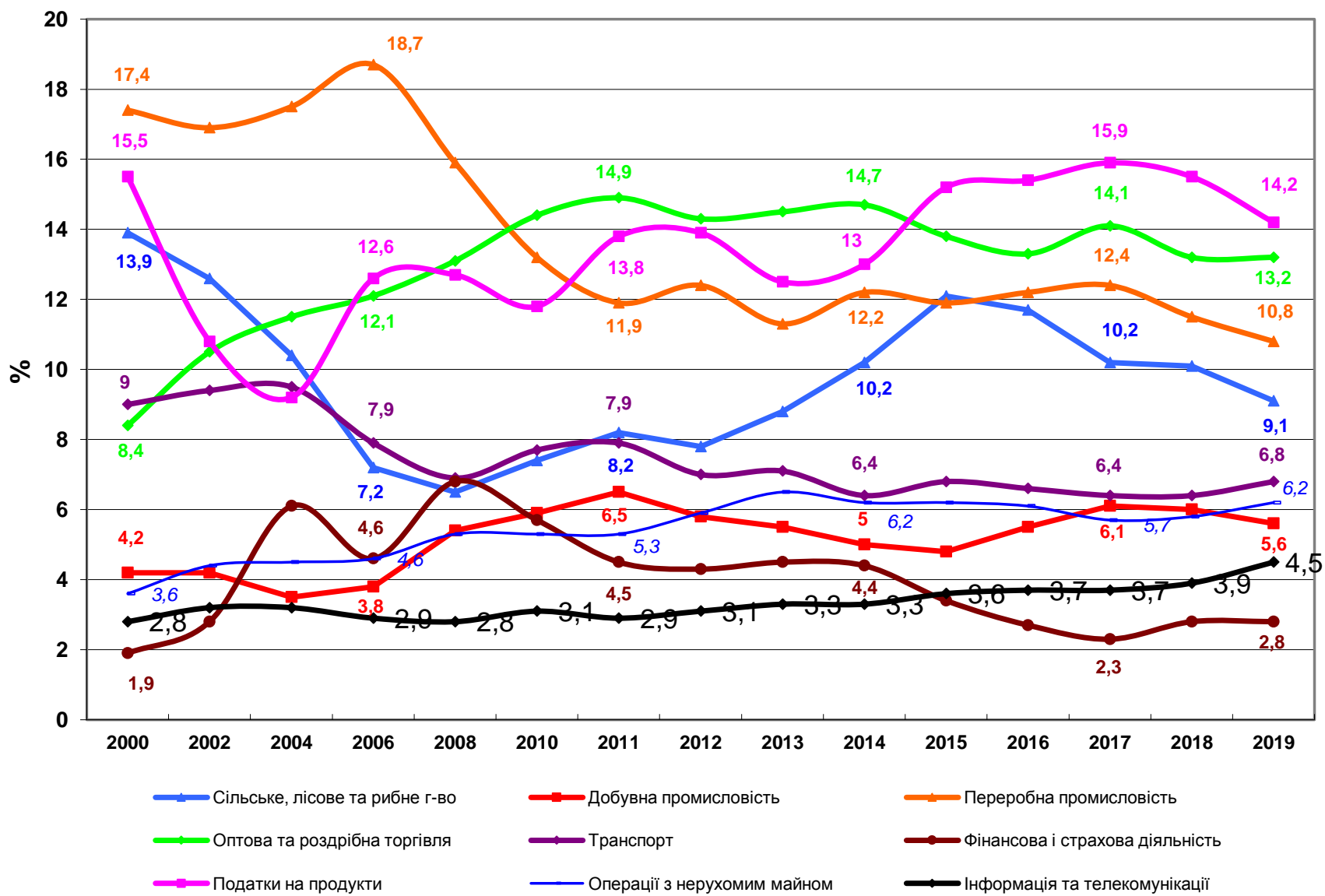

Рис. 7. Структура ВВП (виробничий метод) за основними видами економічної діяльності [20].

Найбільше зменшення номінального ВВП на душу населення у доларовому еквіваленті відбулося у 2009 р. на 34,6\%, коли загострилась фінансово-економічна криза, та в 2014-2015 рр. у середньому на 47,3\%, коли одночасно зменшився обсяг ВВП та різко девальвувала національна валюта. Важливо зауважити, що зростання ВВП на душу населення впродовж 2000-2019 рр. було забезпечене не лише завдяки збільшенню самого ВВП, але і унаслідок негативної динаміки зменшення чисельності населення України протягом аналізованого періоду зменшилося на 7276,6 тис. осіб, або на 14,7\%.

Порівняння ВВП на душу населення в Україні із іншими країнами Європи, демонструє істотні відмінності за рівнем цього показника. Якщо зіставляти із Польщею, нашим сусідом, і Литвою, яка розпочинала ринкові реформи одночасно 3 Україною, то в часовому вимірі за рівнем ВВП на душу населення відставання становить 18-20 років. В абсолютному вимірі, якщо порівняти з 2008 р. та 2013 р. (найбільший ВВП на душу населення в доларовому еквіваленті України), то у Польщі він перевищував український аналог у 3,4 рази, у Литві - 3,9 рази. У 2018 році таке співвідношення аналогічно вже склало 4,9 та 6,2 рази. Водночас у 1992 році Україна і Польща за рівнем ВВП на душу населення стартували, фактично, із різниці у 670 дол. США (Україна - 1420, Польща - 2090), або 1,4 рази на користь Польщі [29].

Такі тенденції свідчать про істотний розрив за рівнями життя між країнами і їх громадянами, про їхню спроможність (неспроможність) забезпечити належний рівень освіти, соціальної адаптації, особистісного та інтелектуального розвитку, конкурентоспроможність на ринку праці, інвестиційні можливості та й, зрештою, людську гідність.

Надважливий вплив на рівень економічного зростання та розвитку національної економіки мають чинники інфляційних і девальваційних процесів, а також політика державного боргу. Протягом 2000-2007 рр. девальваційна політика НБУ (гривні до долара США) та боргова політика уряду фактично не мали негативного впливу на економічне зростання, проте мали позитивний вплив на економічний розвиток (зростання ВВП на душу населення, реальної заробітної плати, зростання чисельності суб'єктів МСП тощо). 
Таблиця 1. Номінальний ВВП на душу населення в Україні й інших країнах [20; 29].

\begin{tabular}{|c|c|c|c|c|c|c|c|c|c|}
\hline \multirow{4}{*}{ Рік } & \multicolumn{6}{|c|}{ Номінальний ВВП на душу населення в Україні** } & \multirow{4}{*}{$\begin{array}{c}\text { Населення } \\
\text { України, } \\
\text { тис. осіб }\end{array}$} & \multicolumn{2}{|c|}{$\begin{array}{c}\text { ВВП на душу } \\
\text { населення }\end{array}$} \\
\hline & \multicolumn{3}{|c|}{ в гривнях (UAH) } & \multicolumn{3}{|c|}{ в доларах США (USD)* } & & \multirow[b]{2}{*}{ Польща } & \multirow[b]{2}{*}{ Литва } \\
\hline & & \multicolumn{2}{|c|}{$\begin{array}{c}\text { Відхилення до } \\
\text { попереднього р., } \\
+/-\end{array}$} & & \multicolumn{2}{|c|}{$\begin{array}{c}\text { Відхилення до } \\
\text { попереднього р., } \\
+/-\end{array}$} & & & \\
\hline & & грн. & $\%$ & & дол. & $\%$ & & \multicolumn{2}{|c|}{ дол. США (USD) } \\
\hline 1 & 2 & 3 & 4 & 5 & 6 & 7 & 8 & 9 & 10 \\
\hline 2000 & 3563 & - & - & 635 & - & - & 49429,8 & 4492 & 3297 \\
\hline 2001 & 4337 & +774 & $+21,7$ & 780 & +145 & $+22,8$ & 48923,2 & 4981 & 3530 \\
\hline 2002 & 4681 & +344 & $+7,9$ & 879 & +99 & $+12,7$ & 48230,3 & 5196 & 4146 \\
\hline 2003 & 5591 & +909 & $+19,4$ & 1048 & $+169,6$ & $+19,3$ & 47813,0 & 5693 & 5505 \\
\hline 2004 & 7272 & +1681 & $+30,1$ & 1367 & $+318,8$ & $+30,4$ & 47451,6 & 6681 & 6707 \\
\hline 2005 & 9371 & +2098 & $+28,9$ & 1828 & $+461,4$ & $+33,7$ & 47105,2 & 7945 & 7863 \\
\hline 2006 & 11630 & +2258 & $+24,1$ & 2303 & $+474,3$ & $+25,9$ & 46787,8 & 9038 & 9240 \\
\hline 2007 & 15496 & +3866 & $+33,2$ & 3068 & $+765,6$ & $+33,2$ & 46509,4 & 11255 & 12298 \\
\hline 2008 & 20494 & +4998 & $+32,3$ & 3891 & $+822,4$ & $+26,8$ & 46258,2 & 14001 & 14961 \\
\hline 2009 & 19832 & -662 & $-3,2$ & 2542 & $-1345,6$ & $-34,6$ & 46053,3 & 11527 & 11140 \\
\hline 2010 & 23600 & +3768 & $+19,0$ & 2974 & $+428,5$ & $+16,8$ & 45870,7 & 12200 & 11953 \\
\hline 2011 & 28813 & +5213 & $+22,1$ & 3570 & $+596,8$ & $+20,1$ & 45693,3 & 13893 & 14357 \\
\hline 2012 & 30912 & +2098 & $+7,3$ & 3855 & $+286,1$ & $+8,0$ & 45633,7 & 13145 & 14341 \\
\hline 2013 & 31988 & +1076 & $+3,5$ & 4030 & $+173,5$ & $+4,5$ & 45553,0 & 13781 & 15693 \\
\hline 2014 & 35834 & +3845 & $+12,0$ & 3104 & $-1015,7$ & $-25,2$ & 45426,2 & 14347 & 16534 \\
\hline 2015 & 46210 & +10376 & $+29,0$ & 2124 & $-899,2$ & $-29,8$ & 42929,3 & 12572 & 14249 \\
\hline 2016 & 55853 & +9643 & $+20,9$ & 2187 & $+70,6$ & $+3,3$ & 42760,5 & 12431 & 14999 \\
\hline 2017 & 70233 & +14370 & $+25,7$ & 2640 & $+455,5$ & $+20,8$ & 42584,5 & 13856 & 16840 \\
\hline 2018 & 84235 & +14002 & $+19,9$ & 3095 & $+455,0$ & $+17,2$ & 42386,4 & 15420 & 19153 \\
\hline 2019 & 94289 & +10054 & $+11,9$ & 3649 & $+554,0$ & $+17,9$ & 42153,2 & - & - \\
\hline
\end{tabular}

Примітки: ${ }^{*}$ - за середнім курсом НБУ за звітний період; ${ }^{* *}-$ у фактичних цінах.

Водночас рівень інфляції, який у 2001 р. різко зменшився на 16 в.п. порівняно із 2000 р., мав позитивний вплив на відтворювальне економічне зростання упродовж 2001-2007 рр. (рис. 8). У цей період, за виключенням після революційного 2005 р., темпи приросту реального ВВП були вищими за рівень інфляції.

Проте у 2008 році національна економіка України потрапила в стан стагфляційної кризи (зафіксовано річне зменшення приросту реального ВВП на 6,0 в.п. (до рівня 2007 р.) у поєднанні зі зростанням річної інфляції до 25,2\%). Внаслідок високого рівня монополізації та офшоризації економіки, виведення спекулятивного фінансового капіталу за межі країни нерезидентами та резидентами, а також неадекватної фінансовоекономічної та монетарної політики влади у 2009 році криза стагфляції набула гостроти: ВВП зменшився до 121,6 млрд. дол. (у порівнянні 3 188,4 млрд. дол. у 2008 р.), інфляція склала 15,9\%, а національна валюта девальвувала майже в 1,5 рази (на 147,9\%).
Водночас найвагомішим наслідком фінансовоекономічної кризи 2008-2009 рр., а відтак одним із визначальних чинників економічного розвитку для наступного десятиліття (2010-2019рр.), про це вже свідчать економічні реалії сьогодення, був старт входження України у «зашморг» державних боргових зобов'язань, зокрема зовнішніх. Так, у 2008 р. темп приросту державного боргу становив 83,3\% до рівня 2007 р., а в 2009 р. та 2010 р. ще додатково 73,6\% та 43,1\% до рівня попередніх років. Загалом за період 2008-2010 рр. державний борг порівняно із 2007 р. збільшився у 2,8 рази, із 14,4 млрд. дол. до 40,8 млрд. дол.

Протягом 2010-2011 рр. економіка за вартісними параметрами відновилася майже до рівня 2008 р. Упродовж 2012-2013 рр. зміни в національній економіці набули ознак рецесії, коли при нульовій інфляції та девальвації зменшився обсяг промислового виробництва (на 0,5 та 4,3 \%), реальний ВВП на рівні $0,2 \%$, але збільшився державний борг до 60,1 млрд. дол. на кінець 2013 p. 


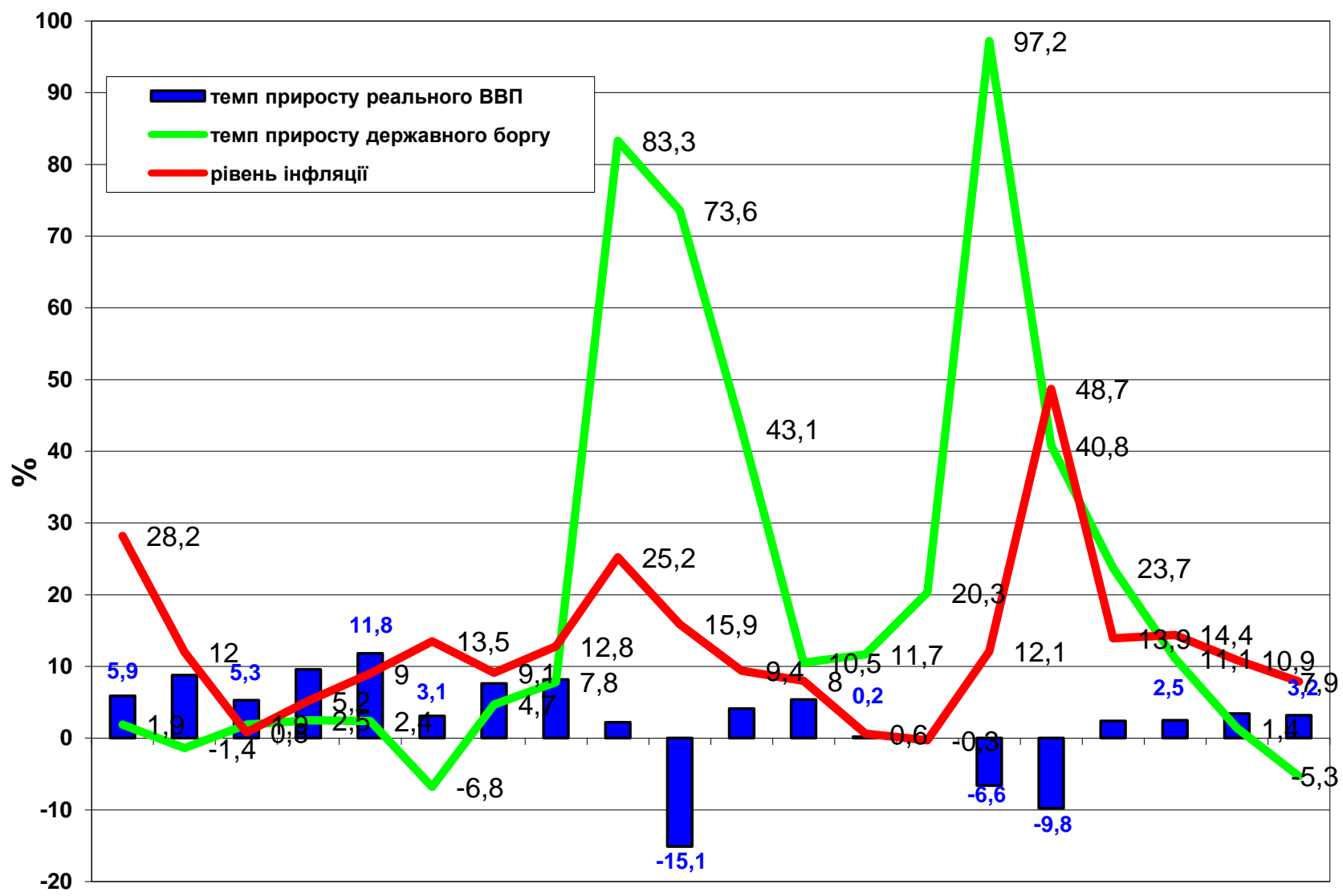

20002001200220032004200520062007200820092010201120122013201420152016201720182019

Рис. 8. Динаміка реального ВВП та темпи приросту державного боргу й інфляції у 2000-2019 рр. (рік до попереднього року) [20].

У 2014 році, внаслідок об'єктивно-суб'єктивних причин, економіка повернулася у стан стагфляційної кризи зразка 2008-2009 рр., але у значно більш руйнівних ії масштабах. Відбулося річне зменшення реального ВВП на $6,6 \%$ у поєднанні із девальвацією гривні на $148,7 \%$, зі зростанням інфляції до 24,9\% на кінець року та приростом державного боргу на 97,2 \%. Внаслідок олігархічних спекулятивних дій стосовно виведення капіталу в офшорні юрисдикції та неповернення валютної виручки в Україну, втрати контролю з боку влади над фінансово-економічною системою та монетарним регулюванням (підвищення ставок за ОВДП, безконтрольне і вибіркове рефінансування приватних банків, зокрема із капіталом країниокупанта РФ), а також непрофесійних і свідомо шкідливих дій уряду, що був залежний від впливу «зовнішніх консультантів» у 2015 році криза стагфляції стала апогеєм руйнування національної економіки України у XXI ст. Зокрема ВВП зменшився до 91,1 млрд. дол. (порівняно з 183,4 млрд. дол. у 2013 р.), річна інфляція сягнула 48,7\% (у квітні 2015 р. рівень був галопуючим - 60,9\%), національна гривня девальвувала в 1,83 рази порівняно із 2014 р. та на 273,3\% порівняно із 2013 р., а приріст державного боргу склав 40,8\%.
У середньостроковому періоді 2014 - 2018 рр. суттєвий вплив на зменшення обсягів виробництва та ВВП зумовили чинники: кінцевого споживчого попиту (обсяг кінцевих споживчих витрат домогосподарств зменшився на 9,9\%); зменшення експорту товарів і послуг на 25,3\%, зменшення чисельності населення - на 6,9\% та доходів населення - на $38,4 \%$.

Після сукупного зменшення національної економіки України в 2014-2015 рр. на 16,4\% та досягнення найнижчої бази ВВП на рівні 91,1 млрд. дол. за крайні 14 років, темпи економічного зростання, що відновилися до рівня 2,4-2,5\% у 2016-2017 рр. та 3,4-3,2\% у 2018-2019 рр., залишаються надто низькими. Така повільна динаміка зростання здебільшого підтримується завдяки багатомільярдному притоку грошових переказів українських заробітчан та нагромадженню державного боргу, який водночас поглиблює кредитну кризу (банки через ОВДП фінансують уряд, а не реальний сектор економіки). Відтак, така неправильна фінансово-економічна та монетарно-банківська політика не дозволила національній економіці упродовж 2016-2019 рр. вийти із фази рецесії (особливо у промисловості), сформувати кількісно і якісно конкурентне 
www.econa.org.ua

середовище на ринках, зменшити рівень бідності, який залишається вищим докризового рівня, та досягти хоч би $1 / 2$ рівня доходів найближчих східноєвропейських держав.

Аналіз динаміки вищезазначених показників свідчить, що і стрімке, і повільне, і від'ємне зростання не можна пояснити суто економічними чинниками. «Вирішальну роль у цій грі відіграють керівництво, політика, урядові структури та ефективність влади» [19, с. 20]. Власне за умов здійснюваної впродовж минулих двадцяти років економічної, фінансової, монетарної, валютної, банківсько-кредитної та власницької політики стабільне економічне зростання в Україні протягом тривалого періоду часу було, та й у майбутньому буде, неможливим.

Такі різкі економічні перепади у темпах економічного зростання та падіння разом із структурною, демографічною, валютною та банківською кризами й галопуючою інфляцією були спричинені низкою чинників, які можна класифікувати за такими групами.

I. Концентраційно-власницькі (стратегічноблокувальні). Економічне зростання, а особливо посткризове, у більшості країн, зазвичай, відбувалося на якісно новій інституційній та виробничо-технологічній основі. Забезпечення ефективної структури національної економіки $\epsilon$ ознакою якості економічного зростання, а його темпи напряму залежать від досконалості та стабільності (гнучкості) інституційного середовища в державі.

Проте одним із парадоксів України $\epsilon$ те, що в до і після кризових періодах на початку 2000-х років, 2008-2009 рр. та 2014-2015 рр., економічне відновлення та зростання продовжувалося на незмінних інституційних засадах, на основі використання наявних виробничих потужностей і дешевої робочої сили, а також за мізерних (або відсутніх) обсягів нових інвестицій з боку власників приватизованих підприємств.

Визначальною системотвірною передумовою цієї непорушної тенденції структурної стагнації української економіки та її хронічною проблемою $є$ - концентрація економічної влади й власності на капітал і засоби виробництва в руках вузького кола фізичних осіб (олігархів) й афільованих ними юридичних осіб, а відтак і політичної влади та їх монопольного впливу на інституційне й секторальне (галузеве) середовище. Усі інші системні питання пов'язані 3 розвитком національної економіки України $€$ наслідком ключової проблеми.

II. Управлінсько-інституційно-лідерські. Управління $є$ принципово важливим чинником. Самих лише сприятливих економічних умов та складових для зростання недостатньо, бо вони можуть забезпечити тільки половину успіху. Друга половина економічних процесів та їх результатів у суспільстві напряму пов'язана з державним управлінням, лідерством, інституціями та політикою, а також їх взаємодією. Ключове завдання національних лідерів (президента, голови уряду) створити в суспільстві консенсус завдяки далекосяжному баченню розвитку нації, підкріпленому економічним зростанням і стратегією розвитку та трансформацій. Суспільний консенсус повинен передбачати добровільне долучення до цього процесу різних верств людей незалежно від рівня розподілу доходів, зокрема науковці, підприємці, робітники, домашні господарства, профспілки, підприємства та організації громадянського й місцевого самоврядування.

Проте сконцентрована економічна влада впродовж років формувала цілком протилежні передумови для здобуття політичної влади, що дозволила здійснювати змістовно-кадровий контроль над інституціями, серед яких основними $€:$ 1) правові інститути (законодавчої і судової системи; захисту прав власності); 2) інститути державного регулювання та управління (бюджетноекономічна політика; податково-митне адміністрування; адміністративні бар'єри; екологічна, науково-інноваційно-промислова політика; регіональна політика); 3) інститути розвитку людського капіталу (освіта; охорона здоров'я; трудові відносини; соціальний захист); 4) інститути координації та розподілу ризиків (фінансово-банківська система; фондовий ринок; страхові компанії).

Оскільки зв'язок між економічним зростанням і якістю національних інститутів $€$ двостороннім: велика їх залежність лобіює вузько корпоративні інтереси i не сприяє якісному зростанню, монополізоване і обмежене для інших зростання пролонгує угодовську сутність «кишенькових» інститутів. В економічній політиці України сформована операційна система, яка 3 єдиного олігархічного центру ухвалює консенсусні рішення стосовно виробництва, структури експорту та імпорту, фінансування і кредитування, розвитку й інновацій, розподілу національного доходу, а також їх законодавче регулювання.

Такий стан сформував в Україні інституційноолігархічну пастку, коли призначена власникамимонополістами залежна і корумпована бюрократія відстоює інтереси виключно своїх покровителів і не прагне здійснювати справедливі для суспільства інституційні та структурні реформи, а україноцентрична й творча частина суспільства, яка здатна протистояти чинній системі та заснувати якісні інститути й створити гідні умови для економічного зростання, $€$ політично заблокована.

III. Регресивно-антиінноваційні. 3 економічної теорії відомо, що ринкові стимули тільки 
www.econa.org.ua

підвищують ефективність і продуктивність, але не ведуть до постійних змін продуктивності й доходів. Зміна сукупної факторної продуктивності в сучасній ринковій економіці - це здебільшого результат інновацій і технічного прогресу або придбання, передачі та використання технологій і знань розвинутих країн у новому середовищі $[19$, с. 55]. Аналогічний висновок робить і Е. Райнерт, який зазначає, що: «зростаюча віддача створює владу над ринком і багатство націй... Всі багаті країни перейшли від бідності до багатства через використання закону зростаючої віддачі: вони відмовились від видобутку сировини та всієї діяльності із спадною віддачею заради промисловості 3 високою доданою вартістю i зростаючої віддачі. Якщо країна оволоділа вітром зростаючої віддачі, то ії економіка приречена на успіх, а суспільство на збільшення багатства» [26].

Технології та знання, навички й ноу-хау впроваджувані на засадах ендогенної теорії зростання та теорії творчого руйнування - мають однаковий вплив на потенційний обсяг виробництва і на продуктивність. Доповнюють цей механізм економічного зростання різноманітні мотиваційні економічні й неекономічні чинники (людська допитливість, прагнення визнання й поваги, бажання послужитися нації), а також системи урядового регулювання й фінансування наукових досліджень.

Проте в Україні руйнівна деіндустріалізація, втрата майже чверті працездатного населення, щорічне зменшення загальних витрат на наукові дослідження й розробки та перетворення її економіки в сировинний придаток глобальних ринків, постали не 3 причини системних стратегічних прорахунків урядових команд, а як цілеспрямовано-координована консенсусна змова кланово-олігархічних груп і «лідерів» держави, які через контрольовані ними коаліційні уряди формували - монопольно-залежну модель національної економіки. Модель економіки в якій домінують види діяльності із спадною віддачею, із дешевою робочою силою, вразливою до найменших криз та зміни цінової кон'юнктури, без конкуренції у базових галузях та серед великих підприємств, де власники приватизованих підприємств незацікавлені у розвитку інноваційного технологічного підприємництва, а розвиток малого і середнього бізнесу утримується в жорстких лещатах контролю та фінансового голоду. Наслідком відсутності адекватної державної регуляторної та інноваційної політики є: звуження промислового потенціалу $\rightarrow$ сповільнення обсягів виробництва $\rightarrow$ експорт сировини та товарів 3 низькою доданою вартістю $\rightarrow$ виведення капіталу $\rightarrow$ низькі заробітні плати $\rightarrow$ дефіцит сукупного попиту $\rightarrow$ низький рівень заощаджень $\rightarrow$ низький рівень внутрішніх інвестицій та залежність від зовнішніх $\rightarrow$ дисбаланс інвестиційних процесів на регіональному рівні $\rightarrow$ нерозвиненість внутрішнього ринку $\rightarrow$ залежність від імпортних товарів кінцевого споживання $\rightarrow$ значний дефіцит торгового балансу $\rightarrow$ зростання державного боргу $\rightarrow$ перманентні валютні й банківські кризи $\rightarrow$ зростання бюджетного дефіциту $\rightarrow$ диспропорції економічного та регіонального розвитку $\rightarrow$ переважання екстенсивного розвитку й відсутність структурних змін $\rightarrow$ гальмування розвитку та еміграція людського капіталу $\rightarrow$ тенета стагнації та бідності.

IV. Воєнно-політичні й зовнішньоекономічні. Агресія, анексія та загарбання українських територій ворожою РФ та володіння власністю стратегічних підприємств на теренах України громадянами РФ, зокрема у сфері енергетики, промисловості, телекомунікації, фінансовобанківській тощо. Диктування умов і нав'язування інструментарію з боку міжнародних інституцій та транснаціональних корпорацій стосовно здійснення економічних трансформацій в Україні, які послабляють національний потенціал і системно узалежнюють українську економіку та ії зростання від зовнішнього середовища i його впливу (пріоритетів).

3 огляду на це варто зруйнувати цю специфічну "олігархічно-консенсусну» рівновагу та перейти до нової стабільної моделі. Але як свідчить український досвід, після кожних президентськопарламентських виборів, двох революцій і навіть зовнішнього впливу (РУВ, агресії та окупації РФ частини території України), автоматичного порушення цієї рівноваги в межах визначеної національної економічної системи - не відбулося. Відтак потрібний інший внутрішній, або зовнішній зсув в національній економіці України, який змінить траєкторії та очікування. Цей імпульс ще може надійти від нового керівництва державою, яке буде обрано на засадах згуртованості українців навколо нового морального лідера, що постане з-за меж середовища «олігархічного консенсусу» та запропонує українській нації модель всеохопності, домінування спільних інтересів, соціальної справедливості й відповідальності, відчуття причетності й впевненості, що виграють усі, а ті, кого спіткає невдача, матимуть захист.

Основою цієї моделі має бути тисячолітня культурна і національна ідентичність українців, яка стане елементом гордості й ціннісним внеском у колективний вибір та управління. Впродовж століть у цій моделі світоглядно нічого не змінюється, окрім впливу нових технологій. 3-решту, цей довгий шлях пройшли старі розвинені країни, ним іде більшість країн, що тепер інтенсивно розвиваються - це шлях розбудови націоналізму, який сприяє далекосяжному колективному й особистому вибору всередині країни. 
www.econa.org.ua

Поштовхом і мотиваційним механізмом моделі стабільного довготривалого зростання є відповідна прагматична й гнучка державна політика, яка наступально зміцнює ендогенні стимули внутрішнього зростання, зміцнює і розширює середній клас у суспільстві, зменшує залежність від попиту промислово розвинених країн та забезпечує спроможність національної економіки керувати власним успіхом.

Рушієм стабільно високих темпів зростання $\epsilon$ потік знань, технологій і фінансових ресурсів, які тісно пов'язані із дотриманням націєцентричного балансу між врегульовано-відкритими ринками глобалізованої економіки та оптимальною протекціоністською стратегією.

Основними завданнями, які потрібно паралельно вирішити в національній економіці України у середньостроковій перспективі для забезпечення внутрішнього зростання і розвитку $€$ такі:

- стимулювати розвиток людино-, капітало- й наукомістких секторів та високотехнологічної промисловості, які повинні домінувати над сировинно- й трудомісткими експортними галузями;

- здійснити перехід до середнього рівня доходів, що спричинить суттєву макроекономічну реструктуризацію економіки та деконцентрацію національного капіталу і власності;

- раціоналізувати та узалежнити від реальної доданої вартості (науко-, інноваційно-, творчомісткої) модель зростання нерівності в доходах;

- збільшити рівень особистих доходів і заощаджень та змінити структуру споживання в бік інвестиційних товарів і послуг;

- підвищити надто низький рівень внутрішніх виробничих інвестицій та зменшити залежність від зовнішнього боргу й некритичного імпорту, а отже, зменшити дефіцит рахунку поточних операцій;

- зорієнтувати інвестиції державного сектору на освіту, науку, інноваційну діяльність, охорону здоров'я, оборону та інфраструктурні проекти, які синергійно розгортатимуть економічну диверсифікацію;

- розвивати модель державно-приватного партнерства, в якій приватний капітал, доповнений стимулами на рівні уряду та місцевого самоврядування, буде компенсацією дефіциту державного фінансування;

- стабілізувати валютний курс гривні із поступовою її ревальвацією (щорічно на 1-3\%), що в комплексі зі зростанням доходів сприятиме необхідним трансформаціям;

- прагматично управляти потоками міжнародного капіталу (зберігати контроль над розміром і складом вхідних потоків капіталу, особливо спекулятивного) для збереження стабільності й узгодження із загальними цілями та завданнями національного росту.

Активатором стимуляції зростання, економічного розвитку та впливовою (зацікавленою) стороною стосовно структурної еволюції економіки дедалі більше ставатиме найчисельніший середній клас і внутрішній ринок.

\section{Висновки і перспективи подальших досліджень}

Національна економіка України перебуває на переломному етапі розвитку. 3 економічнофінансової кризи 2014-2015 років вона вийшла вдвоє ослабленою, і в Україні досі триває війна, частина території окупована РФ, а економіка надалі знаходиться у жорстких лещатах приватних монополій, із високим рівнем безробіття i державного боргу, зменшується промислове виробництво та чисельність населення. Внаслідок різкої девальвації гривні, зменшення обсягу інвестицій та дефіциту бюджетів усіх рівнів загострюється проблема залучення фінансових ресурсів для розвитку підприємств, помірні доходи населення спрямовуються переважно на поточне споживання, яке звужується, а внутрішній ринок непродовольчих товарів на 65-70\% заполонила імпортна продукція. Економічне зростання за таких умов $\epsilon$ малоймовірним. Економічна система України потребує глибокої трансформації, аби сприяти стабільному зростанню, якісному і збалансованому розвитку та структурнорегулювальним цілям в інтересах всього суспільства.

У подальших дослідженнях варто обґрунтувати інструментарій національної економічної політики, що стимулюватиме зростання, пов'язане зі збільшенням населення, збільшенням інвестицій і заощаджень та виробництва продукції, а також зростання викликане науково-інноваційнотехнологічним прогресом України.

\section{СПИСОК ВИКОРИСТАНИХ ДЖЕРЕЛ}

1. Висоцька І. Б. Чинники економічного зростання Фактори економічного зростання: Збірник наук. праць Інституту економіки НАН України К., 2001. С. 4-11.
2. Гаврилишин О. Капіталізм для всіх чи для обраних? Розбіжні шляхи посткомуністичних перетворень / пер. 3 англ. А. Іщенка. 2-ге вид. Київ: ВД «Києво-Могилянська академія», 2007. 384 с.
3. Данилишин Б. Як нам підвищувати темпи економічного зростання. URL: https://ukr.lb.ua.

4. Економічна безпека держави / за заг. ред. О. С. Власюка, А. І. Мокія. Львів: Апріорі, 2013. 836 с. 
wWw econa org.ua

5. Єрохін С. А. Структурна трансформація національної економіки (теоретикометодологічний аспект): монографія. Київ: Світ знань, 2002. $528 \mathrm{c}$

6. Кабаці Б. І. Теоретичні аспекти дослідження впливу фінансовокредитного механізму регулювання на економічне зростання. Науковий вісник Нлту України. 2013. Вип. 23.17. С. 210217.

7. Кемпбелл Р. М., Брю С. Л. Аналітична економія: принципи, проблеми і політика / Пер. з англ. Львів: Просвіта, 1997. 4. 1: Макроекономіка. 671 с.

8. Костенко О. Стимули для прозорості. Цінні папери України. 2008. № 1. C. 17.

9. Макстон Ґ., Рандерс Й. У пошуках добробуту. Керування економічним розвитком для зменшення безробіття, нерівності та змін клімату / пер. з англ. К. Гуменюк, Я. Сотник. 2-ге вид. Київ: Pabulum, 2017. 320 c

10. Малий І. Й., Ємельяненко Л. М., Дзензелюк К. В. Імплементація концепції інклюзивного розвитку В практику регулювання зайнятості населення. Ефективна економіка. 2018. № 12. URL <http://www.economy.nayka. com. ua>.

11. Новий тлумачний словник української мови: В 4-х т. / Укл. В.В. Яременко, О. М. Сліпушко. Київ: Аконіт, 2001. 911 с.

\section{REFERENCES}

1. Vysotska, I. B. (2001). Factors of economic growth. Factors of economic growth, 4-11.[in Ukrainian].

2. Gavrilishyn, O. (2007). Capitalism for all or for the elect? Divergent ways of post-communist transformations. Kyiv: Kyiv-Mohyla Academy [in Ukrainian].

3. Danylyshyn, B. (2020). How do we increase the rate of economic growth. Retrieved from: https://ukr.lb.ua [in Ukrainian].

4. Vlasyuk, O. S., \& Mokiy, A. I. (2013). Economic security of the state. Lviv: Apriori [in Ukrainian]

5. Yerokhin, S. A. (2002). Structura transformation of the national economy (theoretical and methodological aspect). Kyiv: World of Knowledge [in Ukrainian].
12. Оголь Д. О. Економічне зростання: сутність, якість і стійкість. Актуальні проблеми економіки. № 2 ((164)). 2015. С. 67-72.

13. Олена Герасимова. Економічна самодостатність чи занепад? URL: https://www.epravda.com.ua/publi cations/2011/10/11/301359.

14. Пугачевська К. С. Детермінанти експортоорієнтованого розвитку відкритих економік. Бізнес Інформ. № 10. 2019. С. 16-24.

15. Реформація: успіх Європи і шанс для України: кол. моногр. за ред. Р. Шеремети та О. Романенко. Київ: Самміт- Книга, 2017. 256 с.

16. Самуэльсон П., Нордхаус В. Экономика. Economics: Учеб. пособие / Пер. с англ. 16-е изд. М.; СПб.; К.: Вильямс, 2000. 688 с.

17. Сімків Л. Є. Економічне зростання як індикатор якості економічних реформ. Науковий вісник Мукачівського державного університету. Серія Економіка. Випуск 2(4). Частина. 2015. С. 6670.

18. Сірко А. Корпоративна власність у транзитивній економіці. Економіка України. 2003. №2. C. 57-64.

19. Спенс М. Нова конвергенція. Київ: Темпора, 2017. 352 с.

20. Статистична інформація за 20002018 pp. Державна служба статистики України. URL: <http://www.ukrstat.gov.ua.

6. Kabatsi, B. I. (2013). Theoretical aspects of the study of the impact of financial and credit regulatory mechanism on economic growth. Scientific Bulletin of NLTU of Ukraine, 23.17, 210-217 [in Ukrainian].

7. Campbell, R. M., \& Bruce, S. L. (1997). Analytical economy: principles, problems and policy. Lviv: Prosvita [in Ukrainian].

8. Kostenko O. (2008). Incentives for transparency. Securities of Ukraine, 1, 17 [in Ukrainian].

9. Maxton, G., \& Randers, J. (2017). In search of prosperity. Managing economic development to reduce unemployment, inequality and climate change. Kyiv: Pabulum [in Ukrainian].
21. Стійке (стале) економічне зростання. Національний банк України. URL: https://bank.gov.ua/glossary/show/ 275.

22. Тищенко О. П. Інклюзивний розвиток національної економіки України: передумови та домінанти формування стратегії управління. Бізнес Інформ. № 9 . 2019. С. $71-79$

23. Фоміна О. О., Гоголєва Н. Ф. Лабузова Ю. Г. Україна на шляху економічного зростання. Бізнес Інформ. № 10. 2019. С. 8-16.

24. Чухно А. Інституціоналізм: теорія, методологія, значення. Економіка України. 2008. № 7. С. 4-12.

25. Шумпетер Й.А. Капитализм социализм и демократия / Пер. с англ.; Предисл. и общ. ред. В. С. Автономова. Москва: Экономика, 1995. 540 с.

26. Райнерт Эрик С. Как богатые страны стали богатыми и почему бедные страны остаются бедными. 2015

27. Europe 2020: A European strategy for smart, sustainable and inclusive growth. Brussels: European Commission, 2010. 32 p. URL: https://ec.europa.eu/eu2020/pdf.

28. Kuznets S. (1966). Modern Economic Growth. Yale University Press: New Haven. 230 p.

29. World Development Indicators. GDP (current US\$). World Bank. 2019. URL: https://data.worldbank.org.

10. Maly, I. Y., Emelyanenko, L. M., \& Dzenzelyuk, K. V. (2018). Implementation of the concept of inclusive development in the practice of employment regulation. Efficient economy, 12. Retrieved from: http://www.economy.nayka. com.ua [in Ukrainian].

11. Yaremenko, V. V., \& Slipushko, O. M. (2001). New explanatory dictionary of the Ukrainian language. Kyiv: Akonit [in Ukrainian].

12. Ogol D. O. (2015). Economic growth: essence, quality and sustainability. Current economic problems, 2 ((164)), 67-72 [in Ukrainian].

13. Gerasimova, E. (n.d.). Economic selfsufficiency or decline? Retrieved from: https://www. althoughda.com.ua/publications/20 11/10/11/301359 [in Ukrainian]. 
www.econa.org.ua

14. Pugachevskaya, K. S. (2019) Determinants of export-oriented development of open economies. Business Inform, 10, 16-24 [in Ukrainian].

15. Sheremeta, R. and Romanenko, $O$ (2017). Reformation: the success of Europe and a chance for Ukraine. Kyiv: Summit-Book [in Ukrainian].

16. Samuelson, P., \& Nordhaus W. (2000). Economics. M.; SPb ; K.: Williams [in Russian].

17. Simkov, L. E. (2015). Economic growth as an indicator of the quality of economic reforms. Scientific Bulletin of Mukachevo State University. Economics series, 2 (4), 66-70 [in Ukrainian].

18. Sirko, A. (2003). Corporate ownership in a transitional economy. Ukraine economy, 2, 5764 [in Ukrainian].
19. Spence, M. (2017). New convergence. Kyiv: Tempora [in Ukrainian].

20. Statistical information for 20002018. (2018). State Statistics Service of Ukraine. Retrieved from: http://www.ukrstat.gov.ua [in Ukrainian].

21. Sustainable (sustainable) economic growth. National Bank of Ukraine. Retrieved from: https://bank.gov.ua/glossary/show/ 275 [in Ukrainian].

22. Tishchenko, O. P. (2019). Inclusive development of the national economy of Ukraine: prerequisites and dominants of the formation of management strategy. Business Inform, 9, 71-79 [in Ukrainian].

23. Fomina, O. O., Gogoleva, N. F., \& Labuzova, Y. G. (2019). Ukraine on the path of economic growth. Business Inform, 10, 8-16 [in Ukrainian].
24. Chukhno, A. (2008). Institutionalism: theory, methodology, significance. Ukraine economy, 7, 4-12 [in Ukrainian].

25. Schumpeter, J. A. (1995). Capitalism, socialism and democracy. Moscow: Ekonomika [in Russian].

26. Reinert, Eric S. (2015). How rich countries became rich and why poor countries remain poor [in Russian].

27. Europe 2020: A European strategy for smart, sustainable and inclusive growth. (2010). Brussels: European Commission. Retrieved from: https://ec.europa.eu/eu2020/pdf.

28. Kuznets, S. (1966). Modern Economic Growth. Yale University Press: New Haven.

29. World Development Indicators. GDP (current US \$). World Bank. (2019). Retrieved from: https://data.worldbank.org. 